DOI: https://doi.org/10.47405/mjssh.v6i6.814

\begin{tabular}{|c|c|}
\hline 4.581 & Malaysian Journal of Social Sciences and Humanities (MJSSH) \\
\hline $\begin{array}{l}\text { Malaysian Journal of } \\
\text { Social cciences and }\end{array}$ & Volume 6, Issue 6, June 2021 \\
\hline (MJ-SSH) & e-ISSN : 2504-8562 \\
\hline & $\begin{array}{l}\text { Journal home page: } \\
\text { www.msocialsciences.com }\end{array}$ \\
\hline
\end{tabular}

\title{
Pengaruh Iklim Organisasi Ke Atas Sikap Guru Terhadap Perubahan Dalam Pendidikan Abad Ke-21
}

\author{
Mejran Duman', Muhamad Suhaimi Taat', Mohd Khairuddin Abdullah' ${ }^{1}$ \\ 1Fakulti Psikologi dan Pendidikan, Universiti Malaysia Sabah (UMS) \\ Correspondence: Mejran Duman (mejran7781@gmail.com)
}

\begin{abstract}
Abstrak
Kajian ini dilakukan bertujuan untuk mengenal pasti pengaruh iklim organisasi ke atas sikap guru terhadap perubahan dalam pendidikan abad ke-21 dalam kalangan guru sekolah menengah di negeri Sabah, Malaysia. Kajian bukan eksperimental ini menggunakan kaedah tinjauan dan beberapa teknik pensampelan kebarangkalian telah digabungkan untuk mendapatkan sampel. Data dikumpulkan menggunakan satu set borang soal selidik adaptasi yang ditadbir ke atas 440 orang guru. Analisis deskriptif menunjukkan iklim organisasi dan sikap guru terhadap perubahan dalam pendidikan abad ke21 diamalkan pada tahap tinggi. Keputusan ujian ANOVA sehala menunjukkan terdapat perbezaan yang signifikan iklim organisasi dan sikap guru terhadap perubahan dalam pendidikan abad ke-21 berdasarkan pengalaman mengajar. Sementara itu, analisis regresi berganda pula menunjukkan terdapat pengaruh yang signifikan iklim organisasi ke atas sikap guru terhadap perubahan dalam pendidikan abad ke-21. Dapatan menunjukkan sumbangan keseluruhan yang diramal oleh iklim organisasi ke atas sikap guru terhadap perubahan dalam pendidikan abad ke-21 adalah sebanyak 32.9 peratus. Implikasi dan cadangan kajian lanjut turut dibincangkan.
\end{abstract}

Kata kunci: iklim organisasi, sikap guru terhadap perubahan dalam pendidikan abad ke-21, pengalaman mengajar, sekolah menengah

\section{The Influence of Organizational Climate on Teachers' Attitudes Towards Change in The Education of the 21st Century}

\begin{abstract}
This study was conducted to identify the influence of organizational climate on teachers' attitudes towards changes in 21st century education among secondary school teachers in the state of Sabah, Malaysia. This non-experimental study used survey methods and several probability sampling techniques were combined to obtain a sample. Data were collected using a set of adaptation questionnaires administered to 440 teachers. Descriptive analysis shows that organizational climate and teachers' attitudes towards change in 21st century education are practiced at a high level. One-way ANOVA test results show that there is significant difference in organizational climate and teachers' attitudes towards change in 21 st century education based on teaching experience. Meanwhile, multiple regression analysis shows that there is a significant influence of organizational climate on teachers' attitudes towards change in 21 st century education. The findings show that the overall contribution predicted by the organizational climate on teachers' attitudes towards change in 21 st century education is 32.9 percent. Implications and recommendations for further study are also discussed.
\end{abstract}


Keywords: organizational climate, teacher attitudes towards change in 21 st century education, teaching experience, secondary school

\section{Pengenalan}

Kementerian Pendidikan Malaysia (KPM) telah melaksanakan kajian semula terhadap sistem pendidikan negara dalam konteks standard pendidikan antarabangsa. Hasil daripada kajian tersebut, Pelan Pembangunan Pendidikan Malaysia (PPPM) 2013-2025 telah dilancarkan (KPM, 2013). Melalui PPPM 2013-2025, sikap guru terhadap perubahan dalam pendidikan abad ke-21 menjadi persoalan. Adakah guru-guru bersedia melaksanakan setiap perkara yang dirancang. Perubahan-perubahan tersebut menuntut banyak komitmen dan perubahan cara berfikir serta cara bekerja para warganya (Koh Lee Chin, 2014). Sikap positif untuk perubahan didapati penting dalam mencapai matlamat organisasi dan dalam menggantikan program perubahan (Eby et al., 2000; Ab Khalid, Ahmad \& Hamdan 2015; Abdul Aziz, 2015). Untuk memastikan sistem pendidikan tetap menarik dan berdaya saing, pembaharuan sekolah telah menjadi keutamaan di banyak negara di seluruh dunia.

Pembangunan pendidikan negara adalah untuk mencapai kualiti dan juga kecemerlangan pendidikan di samping pembangunan fizikal institusi pendidikan itu sendiri (Tem, 2013). Perkembangan ini telah memberikan implikasi terhadap bidang pendidikan (Mishra \& Koehler 2006). Justeru kajian berkenaan sikap guru terhadap perubahan dalam melaksanakan tugasan hakiki mereka dapat menjawab dan menyelesaikan permasalahan yang berlaku dalam pendidikan pada masa kini secara lebih optimum dan bersifat menyeluruh.

Guru memainkan peranan penting dalam memastikan pencapaian di sesuatu institusi pendidikan (Bai, Piri \& Piri, 2014). Manakala menurut Nurharani, Nur Zahira dan Nur Shaminah (2013) peranan guru adalah sangat penting dalam membentuk masa depan negara. Guru-guru merupakan salah satu faktor utama yang merangsang perubahan yang sedang berlaku kini, namun jika sikap guru terhadap perubahan rendah ini akan menggagalkan pelaksanaan perubahan.

Kajian-kajian yang ketara dalam pengurusan perubahan telah mendapati bahawa faktor penting yang mempengaruhi kejayaan atau kegagalan sebarang perubahan adalah penentangan individu terhadap perubahan yang berkait rapat dengan sikap positif atau negatif untuk berubah (Aslan, Beycioglu \& Konan, 2008; Bouckenooghe, 2009).

Isu berbangkit seperti yang dilaporkan Kementerian Pendidikan Malaysia (2013) ialah sistem pendidikan negara semakin ketinggalan dalam meningkatkan prestasi murid. Malah terdapat dalam kalangan guru-guru dalam abad 21 ini masih menggunakan pendekatan pengajaran berpusatkan guru dan cenderung kepada amalan pengajaran tradisional dengan cara chalk and Talk (Nik Ahmad, 2015; Fadzilah, 2017)

Iklim organisasi juga adalah elemen yang tidak kurang pentingnya dalam pendidikan abad ke-21. Maju dan mundurnya sesebuah organisasi adalah kebijaksanaan pentadbir dalam memimpin warganya (Ali, 2019). Kini, didapati iklim organisasi lebih mencabar kerana banyak perubahan-perubahan yang berlaku dunia pendidikan. Kajian Devos, Tuytens, dan Hulpia (2014) menyatakan bahawa iklim organisasi, sebagai faktor yang berpengaruh. Manakala Wijayanto (2017), membuktikan iklim yang positif mempengaruhi organisasi terhadap prestasi ahli organisasi dan mampu meningkatkan kepuasan dalam melakukan kerja.

Kajian tentang iklim organisasi dianggap penting kerana dilihat sebagai satu faktor peramal dalam pembangunan organisasi (Takele \& Kiltu, 2014). Selain itu persepsi pakar dari iklim organisasi boleh menjadi untuk melihat usaha-usaha organisasi (Venkates, \& Jegajothi Hameed, 2017), sebagai tindak balas kepada polisi semasa dan suasana kerja yang dibentuk (Rahmawati \& Prasetyo, 2017), seterusnya kesan terhadap kepuasan kerja ahli (Ariyani, 2012; Susanti, 2013). 
Penentangan terhadap perubahan dalam kalangan guru merupakan masalah yang sering dikaitkan dengan masalah yang berlaku dalam iklim organisasi (Armenakis et al., 1993; Anghelacha dan Bentea, 2012; Courpasson, Dany, \& Clagg, 2012).

\section{Objektif Kajian}

Kajian ini bermatlamat mengenal pasti pengaruh iklim organisasi ke atas sikap guru terhadap perubahan dalam pendidikan abad ke-21 sekolah menengah di negeri Sabah, Malaysia. Objektif yang disasarkan bagi kajian ini adalah untuk:

i. Mengenal pasti tahap iklim organisasi dan sikap guru terhadap perubahan dalam pendidikan abad ke-21.

ii. Mengenal pasti perbezaan skor min iklim organisasi dan sikap guru terhadap perubahan dalam pendidikan abad ke-21 berdasarkan pengalaman mengajar.

iii. Mengenal pasti pengaruh iklim organisasi ke atas sikap guru terhadap perubahan dalam pendidikan abad ke-21.

\section{Hipotesis Kajian}

Berpandukan objektif kajian, beberapa hipotesis nul telah dibina. Kajian ini menggunakan aras hipotesis nul berikut:

$\mathrm{Ho}^{1}$ Tidak terdapat perbezaan skor min yang signifikan iklim organisasi berdasarkan pengalaman mengajar.

$\mathrm{Ho}^{2}$ Tidak terdapat perbezaan skor min yang signifikan sikap guru terhadap perubahan dalam pendidikan abad ke-21 berdasarkan pengalaman mengajar.

$\mathrm{Ho}^{3}$ Tidak terdapat pengaruh yang signifikan iklim organisasi ke atas sikap guru terhadap perubahan dalam pendidikan abad ke-21.

\section{Tinjauan Literatur}

\section{Sikap Guru Terhadap Perubahan Dalam Pendidikan Abad Ke-21}

Sikap ditakrifkan sebagai tindak balas kecenderungan yang konsisten dan rapi terhadap rangsangan dengan cara yang baik atau tidak baik (Tai \& Omar, 2016). Selain itu sikap juga didefinisikan sebagai perasaan positif atau negatif (kesan penilaian) dalam melakukan gelagat tertentu (Fishbein \& Ajzen, 1975). Sikap guru terhadap perubahan dalam pendidikan abad ke-21 ini menunjukkan tahapnya berapa banyak sokongan individu terhadap perubahan yang berlaku dalam organisasi (Robbins, 1996). Sikap guru terhadap perubahan dalam pendidikan abad ke-21 dalam organisasi dibahagikan kepada tiga dimensi, iaitu: kognitif (pengetahuan), afektif (mahu) dan kecenderungan tingkah laku (Yousef, 2000).

Dalam kajian Vakola dan Nikolaou (2006) mendefinisikan sikap terhadap perubahan sebagai persamaan tertentu perasaan, pemikiran dan kecenderungan individu terhadap perubahan yang dimulakan oleh organisasi. Dalam literatur pengurusan perubahan, majoriti kajian empirikal meramalkan sikap terhadap perubahan telah difokuskan pada dua tema iaitu pemboleh ubah kontekstual dan faktor individu. Pemboleh ubah kontekstual seperti kepercayaan dalam pengurusan. Toprak dan Summak (2014) juga mendapati pengalaman guru tidak menunjukkan perbezaan yang signifikan bagi pemboleh ubah penglibatan dalam perubahan dan komitmen untuk berubah dalam kalangan guru. Seterusnya, Nasri et al. (2017) mendapati tiada perbezaan yang signifikan antara kumpulan kurang berpengalaman dan berpengalaman dalam prestasi guru. 
Azwar (2010) pula menggariskan faktor-faktor yang mempengaruhi sikap. Pertama, pengalaman peribadi merupakan kesan yang ditinggalkan oleh pengalaman peribadi individu menyebabkan ia menjadi asas kepada pembentukan sikap.

\section{Iklim Organisasi}

Litwin dan Stringer's (1968) dan Wirawan (2007), mendefinisikan iklim organisasi sebagai satu set ciri yang boleh diukur tentang persekitaran kerja, mengikut persepsi manusia yang bekerja dalam persekitaran tersebut sama ada secara langsung atau tidak langsung dan dianggap mempengaruhi motivasi dan kelakuan mereka.

Iklim organisasi juga adalah elemen yang tidak kurang pentingnya dalam pendidikan abad ke- 21 . Maju dan mundurnya sesebuah organisasi adalah kebijaksanaan pentadbir dalam memimpin warganya (Ali, 2019). Kini, didapati iklim organisasi lebih mencabar kerana banyak perubahan-perubahan yang berlaku dunia pendidikan kini. Kajian Devos, Tuytens, dan Hulpia (2014) menyatakan bahawa iklim organisasi, sebagai faktor yang berpengaruh. Manakala Wijayanto (2017), membuktikan iklim yang positif mempengaruhi organisasi terhadap prestasi ahli organisasi dan mampu meningkatkan kepuasan dalam melakukan kerja. Kajian tentang iklim organisasi dianggap penting kerana dilihat sebagai satu faktor peramal dalam pembangunan organisasi (Takele \& Kiltu, 2014). Kajian Nortipah (2004) mendapati tidak terdapat perbezaan bagi persepsi kakitangan terhadap iklim organisasi berdasarkan ciri demografi tempoh perkhidmatan. Namun kajian ini sejajar dengan Farah et al. (2016) kerana kumpulan pengalaman mengajar guru didapati menunjukkan perbezaan dalam mempersepsi kan iklim organisasi

Selain itu persepsi pakar dari iklim organisasi boleh menjadi untuk melihat usaha-usaha organisasi (Venkates, \& Jegajothi Hameed, 2017), sebagai tindak balas kepada polisi semasa dan suasana kerja yang dibentuk (Rahmawati \& Prasetyo, 2017). Vakola (2013) menjelaskan perubahan organisasi tidak dapat dilaksanakan dengan berkesan tanpa kesediaan penerima kakitangan untuk mengubah diri, seterusnya menyokong inisiatif yang disarankan. Kajian Maisura Yusop (2007), misalnya, membuktikan pernyataan tersebut apabila mendapati wujudnya pengaruh iklim organisasi terhadap gelagat kewarganegaraan organisasi. kajian Iqbal (2012) menunjukkan bahawa gaya kepimpinan dan iklim organisasi dengan motivasi kerja sebagai pemboleh ubah pengantaraan (intervening) berpengaruh positif dan signifikan terhadap prestasi pekerja. Wan Na (2013) dalam kajian penyelidikannya menunjukkan terdapat perkaitan yang sederhana kuat di antara enam elemen dalam iklim organisasi dengan prestasi kerja

\section{Kerangka Konseptual Kajian}

Dalam kajian ini, sikap guru terhadap perubahan dalam pendidikan abad ke-21 ditetapkan sebagai pemboleh ubah bersandar, manakala iklim organisasi merupakan pemboleh ubah bebas kajian. Dengan bersumberkan Model Dunham et al. (1989), pemboleh ubah bersandar iaitu sikap guru terhadap perubahan dalam pendidikan abad ke-21 telah dibentuk dengan sokongan beberapa teori dan model seperti Teori Konsistensi, Teori Pembelajaran Awal, Teori kap, dan Teori Tindakan Bertujuan (TRA). Berdasarkan tinjauan literatur, didapati wujud pengaruh iklim organisasi ke atas sikap guru terhadap perubahan dalam pendidikan abad ke-21 seperti afektif, kognitif, dan tingkah laku. Oleh itu, iklim organisasi dalam kajian ini ditetapkan sebagai pemboleh ubah bebas yang bersumberkan Litwin dan Stringer (1968). Beberapa teori dan model bagi menjelaskan iklim organisasi dalam kajian ini telah digunakan. Antaranya, Model Litwin dan Stringer, Model Payne dan Pugh, Model Organisasi Berkesan (Mot), Model Organization Health Inventory- OHI, teori Gestalt, teori Fungsional, dan teori Naive Psychology. Melalui kerangka konseptual ini, pengaruh pemboleh ubah peramal terhadap pemboleh ubah kriteria dapat diuji dan seterusnya dijelaskan lebih lanjut. 


\section{Metod Kajian}

Reka bentuk kajian ini ialah bukan eksperimental. menggunakan kaedah tinjauan terhadap sampel, maklumat daripada sebahagian populasi dapat diperoleh. Kajian ini menggunakan pendekatan kuantitatif yang melibatkan analisis statistik deskriptif dan inferensi. Populasi dalam kajian ini di tetapkan hanya dalam kalangan guru-guru sekolah menengah harian biasa yang menerima bantuan penuh kerajaan sahaja. Bersumberkan data yang diperoleh daripada Jabatan Pendidikan Negeri Sabah (2018), terdapat 14,909 orang guru sedang berkhidmat di 200 buah sekolah menengah seluruh negeri. Berdasarkan prinsip-prinsip asas statistik yang perlu dipatuhi untuk analisis data, penyelidik menetapkan saiz sampel kajian sebanyak 440 orang. Dalam kajian ini juga, beberapa kaedah pensampelan kebarangkalian telah digabungkan bagi menjamin kecukupan dan perwakilan populasi. Borang soal selidik merupakan alat ukur utama. Skala pengukuran yang digunakan ialah skala Likert lima mata. Alat kajian yang digunakan untuk mengukur pemboleh ubah bebas iklim organisasi ialah instrumen Litwin dan Stringer, (1968), Stanley (2015), Edaham (2009). Soal selidik ini mengandungi 31 item yang mewakili 7 sub konstruk pemboleh ubah iklim organisasi, iaitu 5 item sub konstruk struktur, 6 item untuk Tanggungjawab, 5 untuk ganjaran, 4 hubungan mesra, 5 untuk sokongan, 5 untuk piawai dan 4 item sub konstruk Identiti. Nilai alpha Cronbach kajian rintis instrumen iklim sekolah ialah 0.81, manakala bagi kajian sebenar ialah 0.92 .

Pemboleh ubah bersandar kajian pula diukur menggunakan "The inventory of attitudes toward change" oleh Dunham, Grube, Gardener, Cummings dan Pierce (1989). instrumen telah diadaptasi dan menjalani proses penterjemahan 'back-to-back'. TATC diguna pakai kerana ia merupakan instrumen yang digunakan secara meluas dalam mengukur sikap guru terhadap perubahan. Soal selidik TATC oleh Dunham, Grube, Gardener, Cummings dan Pierce (1989) telah diguna pakai oleh beberapa penyelidik terdahulu seperti Kursunoglu dan Tanriogen (2009); Vakola et al., (2004); dan Yousef (2000), Buck (2009) serta Jamelaa dan Jainabee (2011); Kin \& Kareem (2017).

Soal selidik yang digunakan bagi mengukur pemboleh ubah sikap guru terhadap perubahan dalam pendidikan abad ke-21 ini terdiri daripada 25 item yang mewakili tiga dimensi utama iaitu 8 item dimensi kognitif, 7 item dimensi afektif, dan 10 item dimensi tingkah laku. Nilai alpha Cronbach kajian rintis soal selidik ini ialah 0.93, manakala bagi kajian sebenar pula ialah 0.95 . Nilai alpha Cronbach tersebut menunjukkan kebolehpercayaan yang tinggi.

\section{Dapatan Kajian}

Analisis terhadap kedua-dua pemboleh ubah kajian berdasarkan pengalaman mengajar menunjukkan skor min yang tinggi. Iklim Organisasi merupakan pemboleh ubah yang menunjukkan nilai skor min di bawah $M=4.000$ bagi semua kumpulan pengalaman iaitu 1 hingga 5 tahun $(\mathrm{M}=3.966, \mathrm{SP}=0.509), 6$ hingga 10 tahun $(\mathrm{M}=3.863, \mathrm{SP}=0.475), 10$ hingga 15 tahun $(\mathrm{M}=3.771, \mathrm{SP}=0.388)$ dan 16 tahun ke atas $(\mathrm{M}=3.736, \mathrm{SP}=0.394)$.

Manakala bagi pemboleh ubah sikap guru terhadap perubahan dalam pendidikan abad ke-21 pula, didapati skor min berpengalaman 10 hingga 15 tahun telah mendapat skor min yang rendah $\mathrm{M}=3.968$, $\mathrm{SP}=0.393$ ). Sebagai rumusan, keputusan skor min berdasarkan pengalaman mengajar secara keseluruhan berada pada tahap yang tinggi bagi semua kumpulan seperti yang dipaparkan dalam Jadual 1.

Jadual 1: Skor Min Variabel Kajian Mengikut Pengalaman Mengajar

\begin{tabular}{llll}
\hline Pengalaman & & IO & SGTP21 \\
\hline \multirow{3}{*}{1 hingga 5 Tahun } & Min & 3.966 & 4.146 \\
& SP & 0.509 & 0.403 \\
& $N$ & 100 & 100 \\
6 hingga - 10 Tahun & Min & 3.863 & 3.997 \\
& SP & 0.475 & 0.346 \\
\hline
\end{tabular}



DOI: https://doi.org/10.47405/mjssh.v6i6.814

\begin{tabular}{llll}
\multirow{2}{*}{10 hingga - 15 Tahun } & Min & 3.771 & 3.968 \\
& SP & 0.388 & 0.393 \\
\multirow{2}{*}{ 16 Tahun ke atas } & N & 89 & 89 \\
& Min & 3.736 & 4.072 \\
\multirow{2}{*}{ Jumlah } & SP & 0.394 & 0.389 \\
& $N$ & 156 & 156 \\
IO - Iklim Organisasi & Min & 3.823 & 4.052 \\
SGTP21 - Sikap Guru Terhadap Perubahan Dalam Pendidikan Abad Ke-21 & \\
\hline
\end{tabular}

\section{Tahap Iklim Organisasi dan Sikap Guru Terhadap Perubahan Dalam Pendidikan Abad Ke-21}

Pengukur iklim organisasi dan sikap guru terhadap perubahan dalam pendidikan abad ke-21 dalam kajian ini adalah berdasarkan tiga tahap skor min, iaitu tinggi, sederhana dan rendah seperti yang dicadangkan oleh Levin \& Rubin (1998). Tahap tersebut ditunjukkan dalam Jadual 2.

Jadual 2: Tafsiran Skor Min

\begin{tabular}{ll}
\hline Nilai Skor Min & Tahap \\
\hline 1.00 hingga 2.33 & Rendah \\
2.34 hingga 3.67 & Sederhana \\
3.68 hingga 5.00 & Tinggi \\
\hline
\end{tabular}

Keputusan analisis skor min bagi iklim organisasi dan sikap guru terhadap perubahan dalam pendidikan abad ke-21 ditunjukkan dalam Jadual 3. Hasil analisis menunjukkan kedua-dua pemboleh ubah diamalkan pada tahap tinggi dengan iklim organisasi sebanyak 3.823 dan sikap guru terhadap perubahan dalam pendidikan abad ke-21 mendapat skor min sebanyak 4.052. Dapatan ini menjelaskan guru di lokasi kajian mempunyai persepsi yang baik pada iklim organisasi terhadap perubahan yang diperkenalkan dalam sistem pendidikan terkini. Demikian juga halnya dengan sikap guru terhadap perubahan dalam pendidikan abad ke-21 turut diamalkan para guru pada tahap tinggi sama ada dalam aspek kognitif, afektif dan tingkah laku.

Jadual 3: Tahap Iklim Organisasi dan Sikap Guru Terhadap Perubahan Dalam Pendidikan Abad Ke-21

\begin{tabular}{llll}
\hline Variabel & $N$ & Min & SP \\
\hline Iklim Organisasi & 440 & 3.823 & .447 \\
Sikap Guru Terhadap Perubahan Pendidikan & 440 & 4.052 & .388 \\
Dalam Abad Ke-21 & & \\
\hline
\end{tabular}

\section{Ho1 Tidak terdapat perbezaan skor min yang signifikan iklim organisasi berdasarkan pengalaman mengajar.}

Berdasarkan analisis deskriptif perbezaan skor min iklim organisasi berdasarkan pengalaman mengajar dalam Jadual 4. Sampel kajian $(N=440)$, didapati skor min guru yang mempunyai pengalaman mengajar 1 hingga 5 tahun adalah lebih tinggi $(\mathrm{M}=3.966, \mathrm{SP}=0.509, N=100)$ berbanding dengan skor min kumpulan responden berpengalaman 6 hingga 10 tahun $(\mathrm{M}=3.863, \mathrm{SP}=0.475, N=95)$, responden berpengalaman 10 Hingga 15 Tahun $(\mathrm{M}=3.771, \mathrm{SP}=0.388, N=89)$ dan berpengalaman 16 Tahun ke atas $(\mathrm{M}=3.736, \mathrm{SP}=0.394, N=156)$. Perbezaan min ini menunjukkan kumpulan responden yang mempunyai pengalaman 1 hingga 5 tahun mengajar mempersepsikan iklim organisasi dengan baik jika dibandingkan dengan tiga kumpulan responden lain. Bukti statistik ini juga mendedahkan bahawa guru 
DOI: https://doi.org/10.47405/mjssh.v6i6.814

berpengalaman mengajar 16 Tahun ke atas mendapat skor min paling rendah berbanding kumpulan responden lain.

Jadual 4: Analisis Deskriptif Variabel iklim organisasi Berdasarkan Pengalaman Mengajar

\begin{tabular}{lllll}
\hline Variabel & & $N$ & M & SP \\
\hline Iklim organisasi & 1 Hingga 5 Tahun & 100 & 3.966 & .509 \\
& 6 Hingga 10 Tahun & 95 & 3.863 & .475 \\
& 10 Hingga 15 Tahun & 89 & 3.771 & .388 \\
& 16 Tahun Ke atas & 156 & 3.736 & .394 \\
& Jum Keseluruhan & 440 & 3.823 & .447 \\
\hline
\end{tabular}

Keputusan analisis ANOVA sehala ditunjukkan pada Jadual 5 yang membuat perbandingan skor min iklim organisasi berdasarkan pengalaman mengajar. Berdasarkan nilai statistik yang diperoleh, iklim organisasi berdasarkan pengalaman mengajar didapati signifikan, $F(d f=3,436)=6.196, p<0.05$. Keputusan ini menunjukkan hipotesis nul $1\left(\mathrm{Ho}^{1}\right)$ ditolak. Justeru, dapatan ini menunjukkan bahawa terdapat perbezaan skor min yang signifikan dalam variabel iklim organisasi berdasarkan pengalaman mengajar. Memandangkan keputusan menunjukkan terdapat perbezaan skor min yang diperoleh dan tidak ditunjukkan dalam analisis ANOVA sehala, maka analisis Post Hoc Multiple Comparisons dijalankan bagi meneliti pasangan skor min dalam kumpulan sama yang menunjukkan perbezaan secara signifikan.

Jadual 5: Analisis ANOVA Sehala iklim organisasi Berdasarkan Pengalaman Mengajar

\begin{tabular}{lllllll}
\hline Variabel & & Ss & $d f$ & $M S$ & $F$ & Sig \\
\hline Iklim & Antara Kumpulan & 3.596 & 3 & 1.199 & 6.196 & .000 \\
organisasi & Dalam Kumpulan & 84.360 & 436 & .193 & & \\
& Jum Keseluruhan & 87.956 & 439 & & & \\
\hline
\end{tabular}

*Signifikan pada tahap $p<0.05$ (2-Hujung)

Jadual 6 memaparkan keputusan analisis Post Hoc Multiple Comparisons yang dilakukan bagi meneliti pasangan skor min dalam kumpulan sama yang menunjukkan perbezaan yang signifikan. Keputusan menunjukkan terdapat perbezaan skor min yang signifikan variabel iklim organisasi berdasarkan pengalaman mengajar, iaitu bagi responden yang mempunyai pengalaman mengajar 1 hingga 5 tahun dengan 10 hingga 15 tahun dan 16 tahun ke atas $(p=0.014)$ dan $(p=0.000)$. Merujuk kepada nilai skor min, kumpulan responden yang berpengalaman mengajar 1 hingga 5 tahun $(\mathrm{M}=3.966)$ adalah lebih tinggi jika dibandingkan dengan responden yang mempunyai pengalaman mengajar 10 hingga 15 tahun $(\mathrm{M}=3.771)$ dan 16 tahun ke atas $(\mathrm{M}=3.736)$. Nilai perbezaan min kedua dua kumpulan ialah sebanyak 0.194 dan 0.229 . Keputusan ini mengesahkan dengan lebih terperinci perbezaan skor min antara kumpulan pengalaman mengajar guru yang menyebabkan hipotesis nul 1 $\left(\mathrm{Ho}^{1}\right)$ ditolak. Justeru, dapatan kajian menyimpulkan bahawa terdapat perbezaan bagi variabel iklim organisasi berdasarkan pengalaman mengajar guru.

Jadual 6: Analisis Post hoc Tukey HSD iklim organisasi berdasarkan Pengalaman Mengajar

\begin{tabular}{lllll}
\hline Variabel & $\begin{array}{l}\text { (I)Pengalaman } \\
\text { Mengajar }\end{array}$ & $\begin{array}{l}\text { (J) Pengalaman } \\
\text { Mengajar }\end{array}$ & $\begin{array}{l}\text { Perbezaan Min } \\
(\mathbf{I}-\mathbf{J})\end{array}$ & Sig \\
\hline Iklim Organisasi & & 6 Hingga 10 Tahun & .102 & .361 \\
& 1 Hingga 5 Tahun & 10 Hingga 15 Tahun & $.194^{*}$ & .014 \\
& & 16 Tahun Ke atas & $.229^{*}$ & .000 \\
& & 1 Hingga 5 Tahun & -.102 & .361 \\
& \multirow{2}{*}{ 6 Hingga 10 Tahun } & 10 Hingga 15 Tahun & .091 & .494 \\
& & 16 Tahun Ke atas & .126 & .123 \\
& 10 Hingga 15 Tahun & 1 Hingga 5 Tahun & $-.194^{*}$ & .014 \\
\hline
\end{tabular}


DOI: https://doi.org/10.47405/mjssh.v6i6.814

\begin{tabular}{llll}
\hline & 6 Hingga 10 Tahun & -.091 & .494 \\
& 16 Tahun Ke atas & .034 & .933 \\
& 1 Hingga 5 Tahun & $-.229^{*}$ & .000 \\
& 6 Hingga 10 Tahun & -.126 & .123 \\
& 16 Thingga 15 Tahun & -.034 & .933 \\
\hline
\end{tabular}

*Signifikan pada tahap $p<0.05$ (2-Hujung)

\section{Ho2 Tidak Terdapat Perbezaan Yang Signifikan Sikap Guru Terhadap Perubahan Dalam Pendidikan Abad Ke-21 Berdasarkan Pengalaman Mengajar}

Berpandukan perbezaan skor min sikap guru terhadap perubahan dalam pendidikan abad ke-21 berdasarkan pengalaman mengajar yang ditunjukkan dalam Jadual 7. Sampel kajian $(N=440)$, didapati skor min guru yang mempunyai pengalaman mengajar antara 1 hingga 5 tahun adalah lebih tinggi $(\mathrm{M}=4.146, \mathrm{SP}=0.403, N=100)$ berbanding dengan skor min kumpulan responden berpengalaman 6 hingga 10 tahun $(\mathrm{M}=3.997, \mathrm{SP}=0.346, N=95)$, pengalaman mengajar 10 hingga 15 tahun $(\mathrm{M}=3.968$, $\mathrm{SP}=0.393, N=89)$ dan pengalaman mengajar 16 tahun ke atas $(\mathrm{M}=4.072, \mathrm{SP}=0.389, N=156)$. Perbezaan skor min menunjukkan kumpulan guru berpengalaman mengajar 1 hingga 5 tahun lebih baik mempersepsikan sikap guru terhadap perubahan dalam pendidikan abad ke-21. Dapatan ini juga menunjukkan guru berpengalaman mengajar 10 hingga 15 tahun adalah kumpulan yang paling rendah secara bandingan dalam mempersepsikan sikap guru terhadap perubahan dalam pendidikan abad ke21.

Jadual 7: Analisis Deskriptif Sikap Guru Terhadap Perubahan Dalam Pendidikan Abad Ke-21 Berdasarkan Pengalaman Mengajar

\begin{tabular}{lllll}
\hline Variabel & & $\boldsymbol{N}$ & M & SP \\
\hline Sikap guru terhadap & 1 Hingga 5 Tahun & 100 & 4.146 & .403 \\
perubahan dalam & 6 Hingga 10 Tahun & 95 & 3.997 & .346 \\
pendidikan abad & 10 Hingga 15 Tahun & 89 & 3.968 & .393 \\
ke-21 & 16 Tahun Ke atas & 156 & 4.072 & .389 \\
& Jum Keseluruhan & 440 & 4.052 & .388 \\
\hline
\end{tabular}

Jadual 8 memaparkan analisis keputusan ANOVA Sehala untuk membandingkan skor min sikap guru terhadap perubahan dalam pendidikan abad ke-21 berdasarkan pengalaman mengajar. Berdasarkan hasil analisis yang diperoleh, sikap guru terhadap perubahan dalam pendidikan abad ke-21 berdasarkan pengalaman mengajar didapati signifikan, $F(d f=3,436)=4.186, p<0.05$. Keputusan ini menunjukkan hipotesis nul $2\left(\mathrm{Ho}^{2}\right)$ ditolak. Dapatan kajian ini menunjukkan bahawa terdapat perbezaan yang signifikan skor min dalam variabel sikap guru terhadap perubahan dalam pendidikan abad ke-21 berdasarkan pengalaman mengajar. Memandangkan keputusan menunjukkan terdapat perbezaan skor min yang diperoleh dan tidak ditunjukkan dalam analisis ANOVA sehala, maka analisis Post Hoc Multiple Comparisons dijalankan bagi meneliti pasangan skor min dalam kumpulan sama yang menunjukkan perbezaan secara signifikan.

Jadual 8: Analisis ANOVA Sehala Sikap Guru Terhadap Perubahan Dalam Pendidikan Abad Ke-21 Berdasarkan Pengalaman Mengajar

\begin{tabular}{lllllll}
\hline Variabel & & $\boldsymbol{S s}$ & $\boldsymbol{d f}$ & $\boldsymbol{M S}$ & $\boldsymbol{F}$ & $\boldsymbol{S i g}$ \\
\hline Sikap guru terhadap & Antara Kumpulan & 1.859 & 3 & .620 & 4.186 & .006 \\
perubahan dalam & Dalam Kumpulan & 64.564 & 436 & .148 & & \\
pendidikan abad ke-21 & Jum Keseluruhan & 66.424 & 439 & & & \\
\hline
\end{tabular}

*Signifikan pada tahap $p<0.05$ (2-Hujung)

Jadual 9 memaparkan keputusan analisis Post Hoc Multiple Comparisons yang dilakukan bagi meneliti pasangan skor min dalam kumpulan sama yang menunjukkan perbezaan yang signifikan. 
Ujian pengesahan menunjukkan terdapat perbezaan skor min yang signifikan variabel sikap guru terhadap perubahan dalam pendidikan abad ke-21 berdasarkan pengalaman mengajar, iaitu bagi responden yang mempunyai pengalaman mengajar 1 Hingga 5 Tahun dengan 6 hingga 10 tahun dan 10 hingga 15 tahun $(p=0.036)$ dan $(p=0.009)$. Merujuk kepada nilai skor min, kumpulan responden yang berpengalaman mengajar 1 Hingga 5 Tahun $(M=4.146)$ adalah lebih tinggi jika dibandingkan dengan responden yang mempunyai pengalaman mengajar 6 hingga 10 tahun $(\mathrm{M}=3.997)$ dan 10 hingga 15 tahun $(M=3.968)$. Nilai perbezaan min kedua-dua kumpulan ialah sebanyak 0.148 dan 0.177 . Keputusan ini mengesahkan dengan lebih terperinci perbezaan skor min antara kumpulan pengalaman mengajar guru yang menyebabkan hipotesis nul $2\left(\mathrm{Ho}^{2}\right)$ ditolak. Justeru, dapatan kajian menyimpulkan bahawa terdapat perbezaan bagi variabel sikap guru terhadap perubahan dalam pendidikan abad ke-21 berdasarkan pengalaman mengajar guru.

Jadual 9: Analisis Post hoc Tukey HSD sikap guru terhadap perubahan dalam pendidikan abad ke-21 Berdasarkan Pengalaman Mengajar

\begin{tabular}{|c|c|c|c|c|}
\hline Variabel & $\begin{array}{l}\text { (I)Pengalaman } \\
\text { Mengajar }\end{array}$ & $\begin{array}{l}\text { (J) Pengalaman } \\
\text { Mengajar }\end{array}$ & $\begin{array}{l}\text { Perbezaan Min } \\
\text { (I-J) }\end{array}$ & Sig \\
\hline $\begin{array}{l}\text { Sikap Guru Terhadap } \\
\text { Perubahan Dalam } \\
\text { Pendidikan Abad Ke-21 }\end{array}$ & 6 Hingga 10 Tahun & $\begin{array}{l}6 \text { Hingga } 10 \text { Tahun } \\
10 \text { Hingga } 15 \text { Tahun } \\
16 \text { Tahun Ke atas } \\
1 \text { Hingga } 5 \text { Tahun } \\
10 \text { Hingga } 15 \text { Tahun } \\
16 \text { Tahun Ke atas } \\
1 \text { Hingga } 5 \text { Tahun } \\
6 \text { Hingga } 10 \text { Tahun } \\
16 \text { Tahun Ke atas } \\
1 \text { Hingga } 5 \text { Tahun } \\
6 \text { Hingga } 10 \text { Tahun } \\
10 \text { Hingga } 15 \text { Tahun }\end{array}$ & $\begin{array}{l}.148^{*} \\
.177^{*} \\
.073 \\
-.148^{*} \\
.028 \\
-.075 \\
-.177^{*} \\
-.028 \\
-.104 \\
-.073 \\
.075 \\
.104\end{array}$ & $\begin{array}{l}.036 \\
.009 \\
.440 \\
.036 \\
.957 \\
.439 \\
.009 \\
.957 \\
.177 \\
.440 \\
.439 \\
.177\end{array}$ \\
\hline
\end{tabular}

*Signifikan pada tahap $p<0.05$ (2-Hujung)

\section{Ho3 Tidak Terdapat Pengaruh Yang Signifikan Iklim Organisasi ke atas Sikap guru terhadap perubahan dalam pendidikan Abad Ke-21.}

Hipotesis Nul 3 (Ho3) telah dianalisis menggunakan Regresi Linear Berganda Stepwise bagi mengukur pengaruh pemboleh ubah peramal terhadap pemboleh ubah kriteria. Pemboleh ubah peramal iaitu iklim organisasi dimasukkan ke dalam model regresi pada aras $p<0.05$. Apabila diproses, didapati pemboleh ubah iklim organisasi diterima sebagai peramal penting terhadap pemboleh ubah kriteria sikap guru terhadap perubahan dalam pendidikan abad ke-21 (Jadual 10).

Jadual 10: Keputusan Analisis Regresi Berganda Stepwise Bagi Pengaruh Iklim Organisasi Ke atas Sikap Guru Terhadap perubahan dalam pendidikan Abad Ke-21

\begin{tabular}{llll}
\hline Variabel peramal & $\boldsymbol{\beta}$ & $\boldsymbol{t}$ & $\boldsymbol{P}($ Sig $)$ \\
\hline Iklim Organisasi & .473 & 10.233 & .000 \\
Maklumat: & & & \\
Iklim Organisasi & & & \\
$R^{2}=.329$ & & & \\
$R^{2}=.32$ & & & \\
$F=214.344$ & & & \\
\hline
\end{tabular}

*signifikan pada tahap $p<0.05$ (2-hujung)

Berdasarkan Jadual 10, nilai koefisien beta dan tahap signifikan bagi pemboleh ubah peramal menunjukkan bahawa seandainya iklim organisasi berubah sebanyak 1 unit, maka varian pemboleh ubah kriteria sikap guru terhadap perubahan dalam pendidikan abad ke-21 turut berubah sebanyak $0.473(\beta=0.473, t=10.233, p<0.05)$. Dapatan kajian juga menunjukkan pengaruh pemboleh ubah 
peramal menyumbang sebanyak $32.9 \%(R 2=0.329)$ ke atas sikap guru terhadap perubahan dalam pendidikan abad ke-21. Oleh itu, terdapat $67.1 \%$ lagi perubahan dalam sikap guru terhadap perubahan dalam pendidikan abad ke-21 tidak dapat diramal mungkin disebabkan faktor-faktor lain yang tidak dikaji dalam kajian ini. Memandangkan nilai signifikan adalah kurang daripada $p<0.50$, maka Hipotesis Nul 3 (Ho3) adalah ditolak. Dapatan kajian ini menunjukkan bahawa iklim organisasi mempunyai pengaruh yang signifikan ke atas sikap guru terhadap perubahan dalam pendidikan abad ke-21.

\section{Perbincangan}

Dapatan kajian ini mempamerkan organisasi sekolah memiliki tahap yang tinggi dalam melaksanakan perubahan dalam pendidikan abad ke-21 ini. Berdasarkan analisis deskriptif, kekerapan guru dalam mempersepsi kan iklim organisasi didapati berada pada tahap tinggi. Tahap sikap guru terhadap perubahan dalam pendidikan abad ke-21. Namun tidak selari dengan dapatan kajian yang diperoleh Wan $\mathrm{Na}$ (2013) dalam kajiannya terhadap pengaruh iklim organisasi terhadap prestasi kerja di kalangan guru yang mengajar di kolej Vokasional yang menunjukkan terdapat perkaitan yang sederhana kuat. Hasil kajian ini sejajar dengan kajian Khaziah dan Fauzi (2016), Talip dan Malinkun, (2020) yang menyatakan bahawa tahap iklim organisasi berada pada tahap yang tinggi.

Kajian ini secara umumnya tidak menyokong kajian Hassan, Rabbani, Shukor Dan Abdul Majid (2018) apabila turut mendapati sikap guru terhadap perubahan dalam kajian mereka berada pada tahap sederhana. Persamaan dapatan juga diperoleh melalui kajian Tai (2017) yang turut mendapati sikap guru terhadap perubahan adalah tidak tinggi. kajian Anghelachea dan Bentea (2012) juga turut mendapati bahawa tahap pelaksanaan sikap guru terhadap perubahan tidak selari dengan kajian ini.

Kajian ini tidak menyokong kajian Nortipah (2004) di mana kajian tersebut tidak terdapat perbezaan bagi persepsi kakitangan terhadap iklim organisasi berdasarkan ciri demografi tempoh perkhidmatan. Namun kajian ini sejajar dengan Farah et al. (2016) kerana kumpulan pengalaman mengajar guru didapati menunjukkan perbezaan dalam mempersepsi kan iklim organisasi dalam pendidikan abad ke21. Dapatan ini menjelaskan bahawa faktor pengalaman mengajar guru di sekolah menengah harian biasa dalam kajian ini mempunyai persepsi yang berlainan tentang amalan iklim organisasi. Melalui literatur, pengalaman mengajar terbukti merupakan faktor demografi yang penting dalam kajian berkaitan sikap guru terhadap perubahan, kerana didapati menunjukkan sebarang perbezaan melalui kajian ini.

Sejajar dengan pandangan Adil (2016) dapatan ini adalah menyokong kebenaran pandangan tersebut bahawa tempoh pengalaman mengajar mampu mempengaruhi amalan dan persepsi guru mengenai sesuatu perkara. Analisis menunjukkan komponen kesediaan perubahan mempunyai kesan berbeza terhadap komitmen perubahan berdasarkan pengalaman mengajar. Dalam konteks kajian ini, pengalaman mengajar menjadi faktor penting yang memberikan perbezaan dari segi persepsi guru berkaitan sikap terhadap perubahan dalam pendidikan abad ke-21. Selain itu, kajian Chew dan Muhamad (2017) pula turut mendapati terdapat hubungan signifikan antara pengalaman mengajar guru dengan aspek kemahiran dalam pelaksanaan penilaian berasaskan sekolah.

Keputusan analisis kajian yang membandingkan sikap guru terhadap perubahan berdasarkan pengalaman mengajar menunjukkan terdapat perbezaan yang signifikan. Hal ini bermakna, tempoh pengalaman mengajar guru menunjukkan sebarang kesan terhadap persepsi mereka berkaitan sikap guru terhadap perubahan. Dapatan kajian ini selari dengan Korry Brenner (2013) menunjukkan sikap guru terhadap perubahan memang berbeza berkaitan dengan pengalaman mengajar selama bertahuntahun, menunjukkan skor min mengenai perubahan total tidak sama. Ini menunjukkan bahawa guru dalam profesion dengan pengalaman 5 tahun atau lebih sedikit akan bertindak balas lebih positif daripada mereka yang berpengalaman 6-10 atau 11 tahun atau lebih dalam pengajaran.

Namun kajian ini tidak menyokong Toprak dan Summak (2014) yang mendapati bahawa pengalaman guru tidak menunjukkan perbezaan yang signifikan bagi pemboleh ubah penglibatan dalam perubahan 
dan komitmen untuk berubah dalam kalangan guru. Seterusnya, Nasri, Vahid Dastjerdy, Eslami Rasekh, dan Amirian (2017) juga turut mendapati tiada perbezaan yang signifikan antara kumpulan kurang berpengalaman dan berpengalaman dalam prestasi guru. Sikap guru terhadap perubahan juga, cenderung akan mempengaruhi komitmen dalam organisasi. Ini kerana ketidakpuasan dalam perubahan yang dilakukan.

Analisis Regresi Linear Berganda Stepwise bagi mengukur pengaruh pemboleh ubah peramal menunjukkan iklim organisasi diterima dalam model regresi sebagai peramal ke atas sikap guru terhadap perubahan dalam pendidikan abad ke-21. Dapatan kajian menunjukkan pengaruh pemboleh ubah peramal menyumbang sebanyak 32.9 peratus ke atas sikap guru terhadap perubahan dalam pendidikan abad ke-21. Hal ini bermakna, terdapat 67.1 peratus lagi perubahan dalam sikap guru terhadap perubahan dalam pendidikan abad ke-21 tidak dapat diramal mungkin disebabkan faktorfaktor lain yang tidak dikaji dalam kajian ini.

Kajian menyimpulkan bahawa terdapat pengaruh iklim organisasi ke atas sikap guru terhadap perubahan dalam pendidikan abad ke-21. Kajian ini menyokong dapatan Maisura (2007), misalnya, membuktikan pernyataan tersebut apabila mendapati wujudnya pengaruh iklim organisasi terhadap gelagat kewarganegaraan organisasi. Berdasarkan pernyataan ini, disimpulkan bahawa iklim organisasi memainkan peranan penting dalam menentukan sikap guru terhadap perubahan yang akan dilakukan oleh organisasi.

Pengaruh iklim organisasi ke atas sikap guru terhadap perubahan dalam pendidikan abad ke-21 dalam kajian ini sejajar dengan kajian Iqbal (2012) menunjukkan bahawa gaya kepimpinan dan iklim organisasi dengan motivasi kerja sebagai pemboleh ubah pengantaraan (intervening) berpengaruh positif dan signifikan terhadap prestasi pekerja. Sementara Wan Na (2013) dalam kajian penyelidikannya menunjukkan terdapat perkaitan yang sederhana kuat di antara enam elemen dalam iklim organisasi dengan prestasi kerja. Ini turut disokong dengan dapatan kajian Reena dan Poonam (2014) menunjukkan bahawa iklim organisasi sekolah tidak mempunyai hubungan rapat dengan kepuasan kerja guru. Namun kajian luar negara oleh Basilius (2015) menunjukkan adanya hubungan dan pengaruh yang signifikan antara iklim organisasi sekolah dengan kepuasan kerja guru dan semangat kerja guru. Sungguh pun demikian, dapatan kajian ini adalah bertentangan dengan kajian kajian Etty (2012) menunjukkan bahawa iklim organisasi tidak mempunyai pengaruh secara signifikan terhadap kepuasan kerja.

\section{Implikasi dan Cadangan}

Penyelidikan ini memberi input terhadap beberapa teori yang mendasari kajian berkaitan sikap guru terhadap perubahan dalam pendidikan abad ke-21 dan iklim organisasi. Kajian ini membuktikan teori dan model yang diguna untuk mewakili setiap variabel adalah menyokong dapatan kajian yang diperoleh. Dapatan menunjukkan iklim organisasi memainkan peranan yang penting dalam mempengaruhi sikap guru terhadap perubahan dalam pendidikan. Ringkasnya, kajian ini membuktikan bahawa teori dan model berkaitan masih relevan dengan situasi semasa.

Hasil kajian ini mendapati sikap guru terhadap perubahan pada tahap tinggi. Sikap guru yang positif pada perubahan adalah syarat yang perlu ada untuk membangun pendidikan negara yang berkualiti. Bagi mencapai matlamat tersebut, guru seharusnya menunjukkan komitmen padu terhadap organisasi. Dalam usaha mengubah persepsi guru-guru pada perubahan yang dilaksanakan, iklim organisasi memainkan peranan penting sebagai medium terhadap perubahan sistem pendidikan. Iklim organisasi yang baik akan dapat membantu meningkatkan keyakinan dan semangat guru-guru dalam melaksanakan tanggungjawab. Kompetensi guru harus seiring dengan perubahan semasa khususnya dari segi afektif, kognitif dan tingkah laku.

Dapatan dalam kajian ini sebagai panduan kepada penyelidik akan datang mengkaji berkaitan iklim organisasi dan pengaruhnya ke atas sikap guru terhadap perubahan dalam pendidikan abad ke- 21 . Peranan faktor demografi terutamanya pengalaman mengajar turut memberi maklumat tambahan 
berkaitan perbezaan antara kedua-dua pemboleh ubah dalam kajian ini. Selain itu, kajian ini dapat menjana idea penyelidik lain khususnya dalam melihat pengaruh faktor-faktor selain iklim organisasi yang tidak dikaji dalam penyelidikan ini berkaitan sikap guru terhadap perubahan dalam pendidikan abad ke-21. Alat ukur kajian yang diguna pakai dalam mewakili setiap variabel sama ada asal mahupun versi terjemahan (bahasa Melayu) dapat membantu penyelidik akan datang untuk kajian berkaitan iklim organisasi dan sikap guru terhadap perubahan dalam pendidikan.

\section{Kesimpulan}

Berdasarkan penemuan kajian, didapati pemboleh ubah bebas iaitu iklim organisasi yang dikaji menunjukkan pengaruh ke atas sikap guru terhadap perubahan dalam pendidikan abad ke-21. Iklim organisasi yang baik membantu guru-guru menentukan kejayaan pelaksanaan sesuatu pembaharuan dalam organisasi pendidikan. Kajian ini membuktikan guru sangat berpengaruh dalam menentukan keberhasilan sebarang perubahan yang dilaksanakan dalam sistem pendidikan negara. Dari sudut perkembangan ilmu, kajian ini menyumbang pengetahuan baharu mengenai pengaruh iklim organisasi ke atas sikap guru terhadap perubahan dalam pendidikan khususnya di Sabah dan amnya di Malaysia. Implikasi dari pembaharuan dalam pendidikan bergantung kepada sikap guru-guru, kerana golongan ini merupakan agen kepada perubahan yang ingin dilaksanakan dalam sesebuah organisasi.

\section{Rujukan}

Ab Khalid, R., Ahmad, J., \& Hamdan, A. (2015). Pembentukan Sikap Positif Guru Terhadap Pelaksanaan Aktiviti Pentaksiran. Journal of Personalized Learning, 1(1), 77.

Abdul Aziz, N. A. B. A. (2015). Hubungan Antara Kepimpinan Instruksional Pengetua Dengan Komitmen Untuk Perubahan Guru Sebagai Mediator Dalam Melaksanakan Pentaksiran Berasaskan Sekolah.

Adil, M. S. (2016). Impact of Change Readiness on Commitment to Technological Change, Focal, and Discretionary Behaviours: Evidence from The Manufacturing Sector of Karachi. Journal of Organizational Change Management, 29(2), 222- 241.

Ali, S. N. N. (2017). Hubungan antara gaya kepimpinan transformasi pengetua dengan komitmen guru pjk di sekolah-sekolah menengah daerah Gua Musang, Kelantan. Proceedings of the ICECRS, 1(1), 123-130.

Anghelachea, V., \& Bentea, C. C. (2012). Educational Changes and Teachers' Attitudes Towards Change. Social and Behavioral Sciences. 33, 593-597.

Armenakis, A. A., Harris, S. G., \& Mossholder, K. W. (1993). Creating readiness for organizational change. Human Relations, 46(6), 681-703.

Aslan, M., Beycioglu, K., \& Konan, N. (2008). Principals' Openness to Change in Malatya, Turkey. International Electronic Journal for Leadership in Learning, 12(8), n8.

Azwar, S. (2010). Sikap Manusia Teori dan Pengukuran nya. Yogyakarta: Pustaka Pelajar.

Bai, N., Piri, R., \& Piri, A. (2014). Investigating school organizational climate and job satisfaction from Kalale physical education teachers' point of view. Research Journal of Sport Science, 2(2), 45-49.

Basilius. (2015). Iklim Organisasi, Kepuasan, Dan Semangat Kerja Guru SD Katolik Kota Merauke Papua, Sekolah Dasar. Tahun 24 Nombor 2, November 2015, hlm 124- 132.

Bouckenooghe, D. (2009). Change recipients' attitudes toward change: a review study (No. 2009-14). Vlerick Leuven Gent Management School.

Brenner, K. (2013). The relationship between elementary general education teachers' self-efficacy and attitude toward change (Doctoral dissertation, Northern Arizona University).

Chew, F. P., \& Muhamad, N. (2017). Readiness of Implementation of School-Based Assessment Among the Malay Language Teachers in National Schools. Advanced Science Letters, 23(3), 2169-2173.

Courpasson, D., Dany, F., \& Clegg, S. (2012). Resisters at work: Generating Productive Resistance in The Workplace. Organization Science, 23(3), 801-819. 
Devos, G., Tuytens, M., \& Hulpia, H. (2014). Teachers' organizational commitment: Examining the mediating effects of distributed leadership. American Journal of Education, 120(2), 205-231.

Dunham, R. B., Grube, J. A., Gardner, D. G., Cummings, L. L., \& Pierce, J. L. (1989). The inventory of change in organizational culture. Madison, WI: Authors.

Eby, L. T., Adams, D. M., Russell, J. E., \& Gaby, S. H. (2000). Perceptions of organizational readiness for change: Factors related to employees' reactions. to the implementation of teambased selling. Human relations, 53(3), 419-442.

Edaham, I. (2009). Peranan Iklim Organisasi dan Ciri Personaliti terhadap Prestasi Kerja (Doctoral dissertation, Universiti Utara Malaysia).

Etty Susanty. (2012). Pengaruh Iklim Organisasi Terhadap Kepuasan Kerja Dan Komitmen Karyawan Pada Universitas Terbuka. Jurnal Organisasi dan Manajemen, 8(2), 121-134.

Fadzilah, A. H. (2017). Pelaksanaan pengajaran dan pembelajaran koperatif berasaskan abad ke-21: satu tinjauan di Sekolah Menengah Kebangsaan Pekan Nenas (Doctoral dissertation, Universiti Tun Hussein Onn Malaysia).

Farah Liana Hamdan, \& Mohd Izham Mohd Hamzah (2016). Pengaruh Iklim Organisasi Terhadap Kepuasan Kerja Dalam Kalangan Pensyarah Kolej Poly- Tech MARA (KPTM). e-Proceeding of the 4th Global Summit on Education 2016, (pp. 304-313).

Fishbein, M. \& Ajzen, I. (1975). Belief, attitude, intention and behavior: An introduction to theory and research. Reading, MA: Addison - Wesley.

Hassan, M.A.A., Rabbani, M.F., Shukor, M.E.M. and Majid, M.M.A., (2018). Sikap Guru Terhadap Perubahan dalam Sekolah di Malaysia. Management Research Journal, 7, 188-196.

Iqbal Nazili Nim. (2012). Pengaruh Gaya Kepemimpinan Dan Iklim Organisasi Terhadap Kinerja Karyawan: Motivasi Kerja Sebagai Variabel Intervening Fakultas Ekonomika Dan Bisnis. Universitas Diponegoro Semarang.

Jamelaa Bibi Abdullah dan Jainabee Md Kassim. (2011). Instructional Leadership and Attitude Towards Organizational Change Among Secondary Schools Principal in Pahang, Malaysia. Procedia Social and Behavioral Sciences, 15, 3304- 3309.

Kementerian Pendidikan Malaysia. (2013). Pelan Pembangunan Pendidikan Malaysia 2013-2025 (Pendidikan Prasekolah hingga Lepas Menengah). Putrajaya: Malaysia.

Khaziah \& Fauzi. (2016). Pengaruh Iklim Organisasi Terhadap Kepuasan Kerja Guru Di Sekolah Menengah Dalam Daerah Kuala Terengganu. International Seminar on Generating Knowledge Through Research, UUM-UMSIDA, 25-27 October 2016, Universiti Utara Malaysia, Malaysia.

Kin, T. M., \& Kareem, O. A. (2017). Measuring teacher attitudes towards change: an empirical validation. International Journal of Management in Education, 11(4), 437-469.

Koehler, M. J., Mishra, P., \& Yahya, K. (2007). Tracing the Development of Teacher Knowledge in A Design Seminar: Integrating Content, Pedagogy and Technology. Computers \& Education. 49(3), 740-762.

Koh, L.C., (2014). Ciri-ciri organisasi pembelajaran mengikut persepsi guru di sekolah sekolah menengah di Malaysia/Koh Lee Chin (Doctoral dissertation, University Malaya).

Kursunoglu, A. (2009). An Investigation of Organizational Trust Level of Teachers According to ome Variables. Procedia Social and Behavioral Sciences, 1, 915-920.

Litwin, G. H., \& Stringer, R. A. (1968). Motivation and organizational climate. Boston, MA: Harvard University Press.

Maisura M. Yusof. (2007). Iklim Organisasi dan Hubungannya dengan Gelagat Kewarganegaraan Organisasi di Kalangan Guru-Guru Sekolah Menengah Daerah Pontian Johor. Skudai, Johor. Universiti Teknologi Malaysia.

Nasri, N., Vahid Dastjerdy, H., Eslami Rasekh, A., \& Amirian, Z. (2017). Iranian EFL Teachers' Practices and Learner Autonomy: Do Gender, Educational Degree, and Experience Matter? Innovation in Language Learning and Teachin,. 11(2), 146-158.

Nik Ahmad N. N. A. (2015). Pendidikan Kelas Abad Ke-21. Dewan Bahasa dan Pustaka Wilayah Timur. Sinar Harian Sdn. Bhd.

Nor Tipah, M. (2004). Iklim Organisasi dan Prestasi Kerja: Kajian di Jabatan Kebajikan Masyarakat Negeri Pahang (Doctoral dissertation, Universiti Utara Malaysia).

Nurharani Selamat, Nur Zahira Samsu \& Nur Shaminah Mostafa Kamalu. (2013). The impact of organizational climate on teachers' job performance. 
Reena Rani \& Poonam Rani. (2014). Influence of Organizational Climate of Elementary Schools on Job Satisfaction of Elementary Teachers. International Journal of Science, Environment and Technology, 3(2), 2014, $652-658$.

Robbins, M. S., Alexander, J. F., Newell, R. M., \& Turner, C. W. (1996). The immediate effect of reframing on client attitude in family therapy. Journal of Family Psychology, 10(1), 28-34.

Stanley Anak Abang. (2015). Pengaruh Keselarasan Personaliti dan Environment Kerja, Iklim Organisasi dan kepuasan Kerja Terhadap Komitmen Pengajaran Guru Di Sekolah Menengah Berprestasi Rendah Di Sarawak, Malaysia, Universiti Malaysia Sabah.

Tai, M. K., Omar, A. K. (2016). Teacher Attitudes toward Change: A Comparison between High-and Mediocre-Performing Secondary Schools in Malaysia. International Studies in Educational Administration (Commonwealth Council for Educational Administration \& Management (CCEAM)), 44(1)

Takele, Y., \& Kiltu, M. R. (2014). Employees' Perception of Organizational Climate and Its Implications for Organizational Effectiveness in Amhara National Regional State, Ethiopia. Ethiopian Journal of Business and Economics (The), 4(1), 116-148.

Talip, R. B., \& Malinkun, R. B. (2020). Hubungan Iklim Organisasi Sekolah dan Kompetensi Kecerdasan Emosi Guru Sebagai Mediator ke atas Kualiti Guru Generasi" Y" di Sekolah Menengah Daerah Kudat. Malaysian Journal of Social Sciences and Humanities (MJSSH), 5(3), 58-78.

Tem, E., \& Na, W. (2013). Pengaruh iklim organisasi ke atas prestasi kerja guru di kolej vokasional (Doctoral dissertation, Universiti Tun Hussein Onn Malaysia).

Toprak, M., \& Summak, M. S. (2014). Involvement in Change and Commitment to Change: A Study at Public Schools. International Journal of Social Sciences \& Education, 4(4), 953-968.

Vakola, M. \& Nikolaou, I. (2006). Attitudes toward organizational change: What is the role of employees, stress and commitment? Employee Relations, 27(2), 160-174.

Vakola, M. (2013). Multilevel Readiness to Organizational Change: A Conceptual Approach. Journal of Change Management,13(1), 96-109.

Vakola, M., Tsaousis, I., \& Nikolaou, I. (2004). The Role of Emotional Intelligence and Personality Variables on Attitudes Toward Organizational Change. Journal of Managerial Psychology. 19(2): 88-110.

Venkatesh, M., Jegajothi, S. S. \& Hameed, M.S. (2017). A Study on Organizational Climate At Jbm Auto System Pvt Ltd, Chennai. International Journal SSRG, 76-80.

Wan Na A/P Eh Tem. (2013). Pengaruh Iklim Organisasi Ke Atas Prestasi Kerja Guru Di Kolej Vokasional. Tesis Ijazah Sarjana. Universiti Tun Hussein Onn Malaysia.

Wijayanto, S. A. (2017). Dampak iklim organisasi terhadap kebahagiaan dan kinerja karyawan (studi pada Universitas Muhammadiyah Yogyakarta). Jurnal Bisnis, Manajemen, dan Akuntansi, 4(1).

Yousef, D. A. (2000). Organizational commitment: A mediator of the relationships of leadership behaviour with job satisfaction and performance in a non-western country. Journal of managerial Psychology, 15(1), 6-24. 